\title{
DISGS

\section{Vitrinite Reflectance Measurements of Cretaceous Outcrop Samples from the Wyoming Thrustbelt, Southwestern Wyoming}

by Mark Pawlewicz ${ }^{1}$ and Mark Kirschbaum ${ }^{1}$

This report is preliminary and has not been reviewed for conformity with U.S. Geological Survey editorial standards or with the North American Stratigraphic Code. Any use of trade names is for descriptive purposes only and does not imply endorsement by the U.S. Government.

Open-File Report 2004-1360

U.S. DEPARTMENT OF THE INTERIOR

U.S. GEOLOGICAL SURVEY

${ }^{1}$ Denver, Colorado 


\title{
Vitrinite Reflectance Measurements of Cretaceous Outcrop Samples from the Wyoming Thrustbelt, Southwestern Wyoming
}

\section{By}

\author{
Mark Pawlewicz and Mark Kirschbaum
}

\begin{abstract}
Eleven outcrop samples from the Wyoming thrustbelt region in southwestern Wyoming (fig. 1) were collected for analysis as part of the U.S. Geological Survey's ongoing oil and gas assessment project for selected basins in the western United States. The samples are all Cretaceous in age (fig. 2). Latitude and longitude data were obtained with a global positioning system unit. The lithology of these samples is either mudstone or coal.
\end{abstract}

The samples were examined with a reflected light microscope to determine their degree of thermal maturity by vitrinite reflectance. Sample quality and abundance of organic matter were good except for one mudstone (number 3 in table 1) where the presence of organic matter was reduced because of its lithology. The results of the analyses are listed in table 1. 


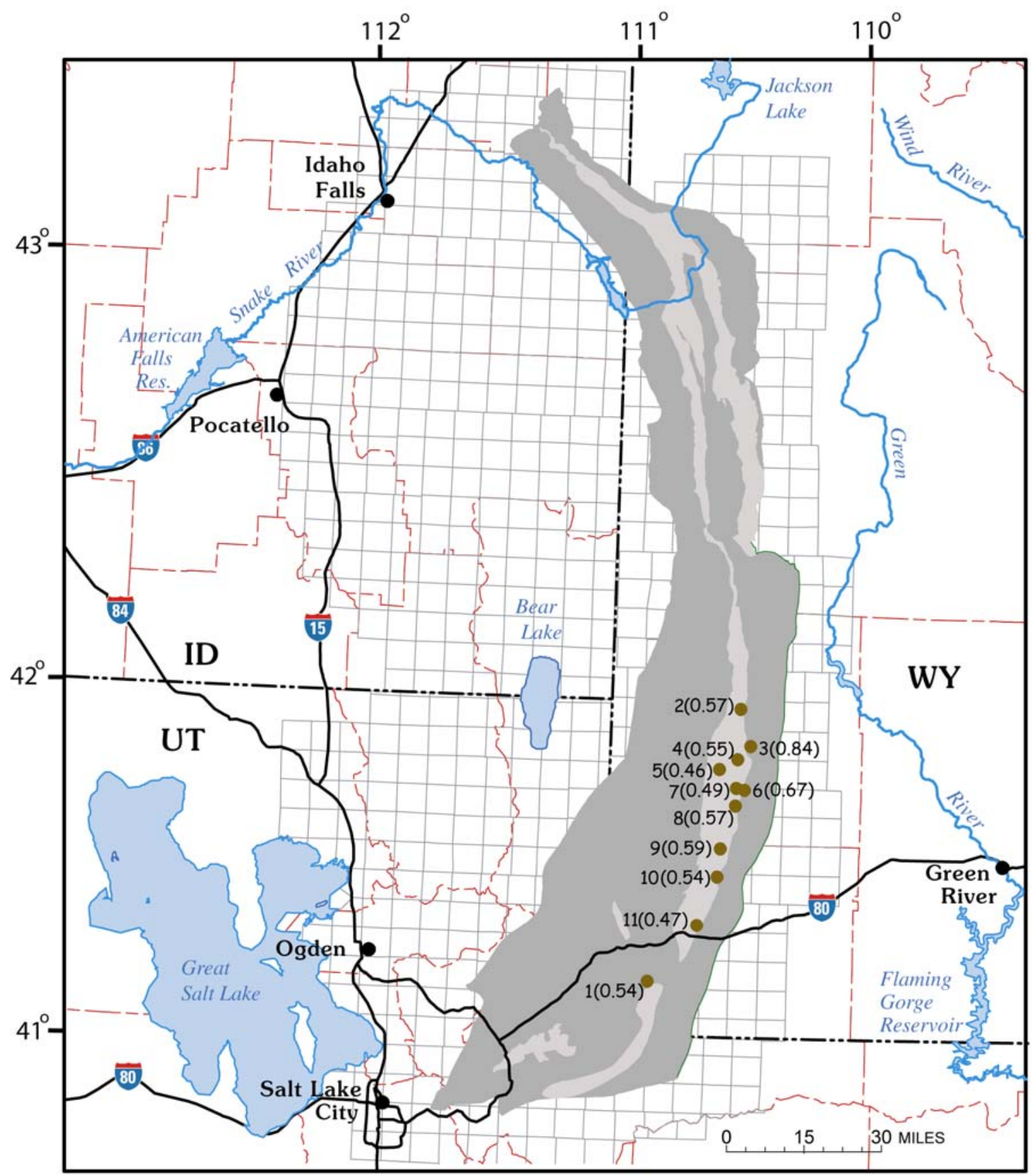

Figure 1. Wyoming thrustbelt region of southwestern Wyoming with sample locations plotted. First number refers to map no. in table 1. Numbers in parentheses are mean vitrinite reflectance values, also listed in table 1. Darker gray color is general outline of Wyoming thrustbelt region, and the lighter gray color represents general location of Cretaceous coal. 


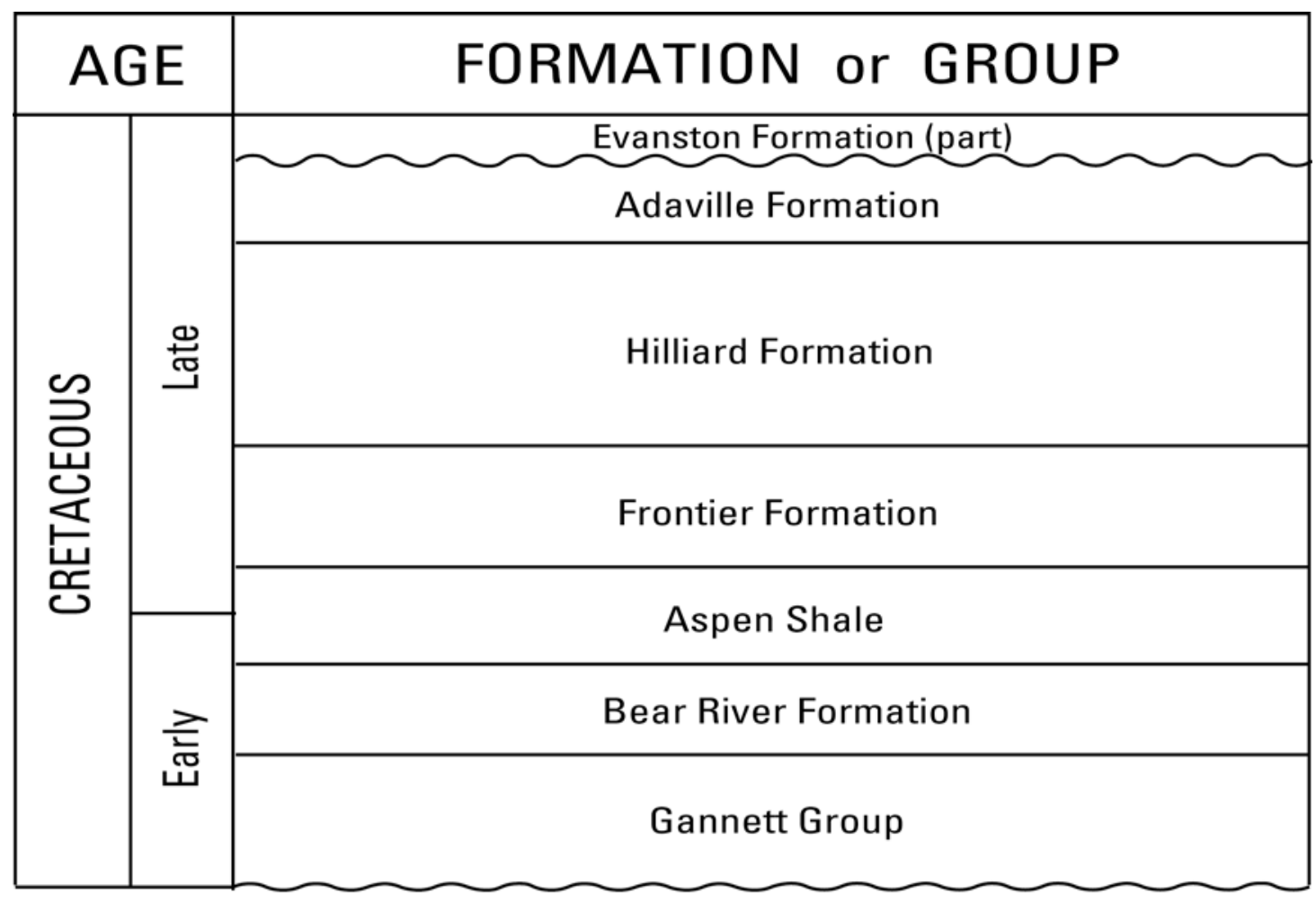

Figure 2. Generalized stratigraphic section for Cretaceous rocks of Wyoming thrustbelt region of southwestern Wyoming. 
Table 1. Mean vitrinite reflectance values and locations for Wyoming thrustbelt samples in southwestern Wyoming.

[Map no. refers to numbers plotted in figure 1. Ro, vitrinite reflectance in percent; n, number of measurements;

Ceno., Cenomanian; Fm, Formation; Mbr, Member.]

\begin{tabular}{cccccccccc}
\hline Map no. & Formation & Age & Longitude & Latitude & Lithology & State & County Ro (mean) & n \\
\hline & & & & & & & & & \\
1 & Bear River Fm. & Albian & -110.8641 & 41.1635 & mudstone & WY & Uinta & 0.54 & 27 \\
2 & Frontier Fm, Dry Hollow Mbr. & Cenomanian & -110.5245 & 41.9862 & coal & WY & Lincoln & 0.57 & 31 \\
3 & Aspen Shale & Albian/Ceno. & -110.4806 & 41.8756 & mudstone & WY & Lincoln & 0.84 & 9 \\
4 & Frontier Fm, Dry Hollow Mbr. & Cenomanian & -110.5309 & 41.8352 & coal & WY & Lincoln & 0.55 & 27 \\
5 & Adaville Formation & Campanian & -110.6028 & 41.8043 & coal & WY & Lincoln & 0.46 & 25 \\
6 & Aspen Shale & Albian/Ceno. & -110.5005 & 41.7438 & mudstone & WY & Lincoln & 0.67 & 15 \\
7 & Frontier Fm, Dry Hollow Mbr. & Cenomanian & -110.5337 & 41.7491 & coal & WY & Lincoln & 0.49 & 25 \\
8 & Frontier Fm, Chalk Creek Mbr. & Cenomanian & -110.535 & 41.6962 & coal & WY & Lincoln & 0.57 & 29 \\
9 & Frontier Fm, Chalk Creek Mbr. & Cenomanian & -110.0592 & 41.5772 & coal & WY & Uinta & 0.59 & 27 \\
10 & Frontier Fm, Chalk Creek Mbr. & Cenomanian & -110.6000 & 41.4818 & coal & WY & Uinta & 0.54 & 25 \\
11 & Frontier Fm, Oyster Ridge Mbr. & Cenomanian & -110.675 & 41.3364 & coal & WY & Uinta & 0.47 & 25 \\
\hline
\end{tabular}

